Egyptian Journal of Aquatic Biology \& Fisheries

Zoology Department, Faculty of Science,

Ain Shams University, Cairo, Egypt.

ISSN $1110-6131$

Vol. 24(7): 93 - 117 (2020)

www.ejabf.journals.ekb.eg

\title{
Bacteriophages: Ecological role in the marine environment and potential applications
}

\author{
Sahar W. M. Hassan, Hanan Abd-EINaby, Gehan M. Abou-Elela,
}

Ahmed E. Abouelwafa , Nermeen A. El-Sersy *

Marine Microbiology Lab., Environmental Division, National Institute of Oceanography and Fisheries (NIOF), Egypt.

*Corresponding author: nermeen_ok @yahoo.co.uk

\section{ARTICLE INFO}

Article History:

Received: Sept. 3, 2020

Accepted: Oct. 7, 2020

Online: Oct. 17, 2020

Keywords:

Bacteriophages,

Ecological role,

Applications,

Phage therapy.

\begin{abstract}
Bacteriophages are the most plentiful organisms on the earth and they are a ubiquitous trait of prokaryotic existence. They exist in all environments as a part of a complex microbial ecosystem. A phage is a virus that can infect bacteria where the distribution and abundance are based on the host organisms. Bacteriophages can impact their host populations in different ways and also have impacts on the microbial ecology and geochemical cycles. The concept of phage therapy as a fundamental application of bacteriophages is deeply relying on the facts of their host specificity, abundance in the environment with limited ecological impact. This review focuses on the ecological role of bacteriophages in the marine environment and some applications.
\end{abstract}

\section{INTRODUCTION}

Bacteriophages (phages) are bacteria-specific viruses. They are the most abundant biological entities on earth (Katsamba and Lauga, 2019). They exist in all ecosystems. The microbiota of healthy humans also contains a large number of bacterial viruses (Van Belleghem et al., 2019). However, presentation of their genomic sequences in public databases is still limited. It was reported that only 1956 bacteriophage genomes are currently available (Kazimierczak et al., 2019).

The ecological role of bacteriophages has an effect on bacterial existence, diversity in the ocean, biogeochemical cycles, regulation of nutrients and they are the key players of horizontal gene transfer and control of bacterial population size (Breitbart et al., 2018).

Antimicrobial resistance is a main public health problem that can possibly cause an expected 10 million mortalities per year by 2050 (Sugden $\boldsymbol{e t}$ al., 2016). The crisis of antimicrobial resistance has been attributed to the absence of new agents or misuse of 
these agents. Inclusive efforts are needed to reduce the pace of resistance and find suitable alternatives (Baloch et al., 2018).

Recently, bacteriophages have been proposed as alternatives to antibiotics for many antibiotic resistant strains and have been applied in different fields of medical science and biotechnology including rapid detection and control of bacterial diseases (Oechslin, 2018).

Regarding this concept, the use of phage therapy in aquaculture seems to be very promising, the most feasible and suitable candidate to overcome the problems of antibiotic resistance. Bacteriophages are believed to protect fish against different pathogens and decrease the side-effects for the humans and environment. In aquaculture, addition of bacteriophages to live feeds, such as rotifers or Artemia, is an efficient method to purify the feeds before the entry to invertebrate or fish and provides less risk of bacterial resistance. In addition, they can be added in rearing tanks, which permit for coevolution of phage-bacteria.

\section{History of bacteriophages}

The history of bacteriophage discovery started when Ernest Hankin, a British bacteriologist, reported in 1896 the presence of antibacterial activity against Vibrio cholerae in the waters of the Ganges and Jumna rivers in India, caused by unidentified source (which passed through fine porcelain filters and was heat labile) and was responsible for the elimination of cholera epidemics (Kirby, 2012).

Two years later, the Russian bacteriologist Gamaleya observed a similar phenomenon while working with Bacillus subtilis (Marza et al., 2006). The rediscovery of bacteriophages by d'Herelle is frequently associated with an outbreak of severe hemorrhagic dysentery among several soldiers and he was assigned to make a realization for this incident.

\section{Structure of bacteriophages}

The classical structure of bacteriophage is composed of head and tail (Fig. 1). The head is a coat of protein and has an icosahedron shape and comprise the genetic material of the phage. The tail exhibits six tail fibers with receptors to recognize specific sites on the bacterial surface. It was stated that the morphology and nature of each bacteriophage determine the action used by the bacteriophage to inject its genome and also determine the style of its life cycle (Mansour, 2018). 


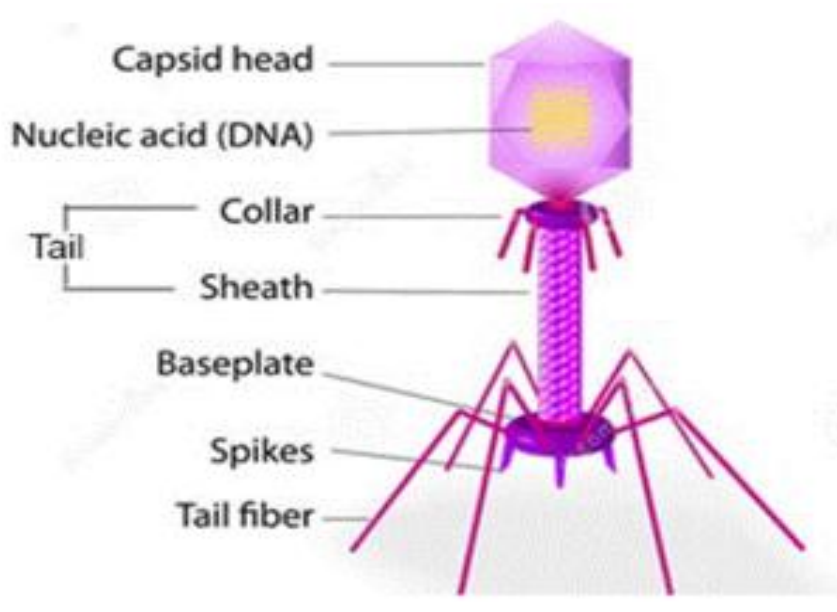

Fig1: Typical bacteriophage structure (Mansour, 2018).

\section{Classification of bacteriophages}

Eukarya, Bacteria and Archaea are the main domains of life and contain cellular organisms (Woese et al., 1990). Bacteriophges cannot be incorporated into these domains due to lack of ribosomal RNA nucleotide sequence (Rohwer and Edwards, 2002), although sensitivity to infection with bacteriophges is a common feature in these domains.

Classification is mainly used to detect relationships among bacteriophages, to identify novel bacteriophage with industrial or therapeutic applications or harmful bacteriophages in fermentation industry for eradication and control purposes (Kutter and Sulakvelidze, 2005). Bacteriophages are classified into 13 families based on their virion morphology and the nature of their encapsidated nucleic acid (Hanlon, 2007). The three main families belonging to the Caudovirales are Siphoviridae, Myoviridae and Podoviridae (Kutter and Sulakvelidze, 2005; Lopes et al., 2014).

The families with dsDNA are: Fuselloviridae (pleomorphic, envelope, lipids, no capsid), Lipothrixviridae (enveloped filaments, lipids), Corticoviridae (icosahedra capsid with lipid layer), Siphoviridae (long, non-contractile tail), Tectiviridae (icosahedral capsid with inner lipoprotein vesicle), Plasmaviridae (pleomorphic, envelope, lipids, no capsid), Podoviridae (short, non-contractile tail), Rudiviridae (helical rods), Myoviridae (contractile tail), Inoviridae (rod-shaped with helical symmetry) and Microviridae (icosahedral capsid) (Thung et al., 2018) (Fig. 2).

The families with ssRNA and dsRNA are Leviviridae (quasi-icosahedral capsid) and Cystoviridae (enveloped, icosahedral capsid, lipids), respectively. It was reported that more than $96 \%$ of bacteriophages are tailed phages (Ackermann, 2007), belong to the order Caudovirales and exhibit varied properties, such as composition and content of 
DNA, nature of constitute proteins, host range, serology, and physiology (Kutter and Sulakvelidze, 2005).

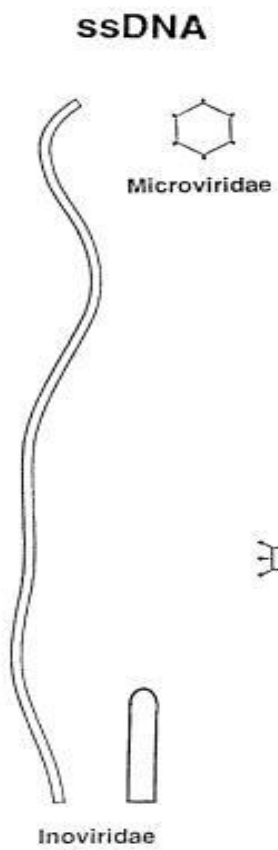

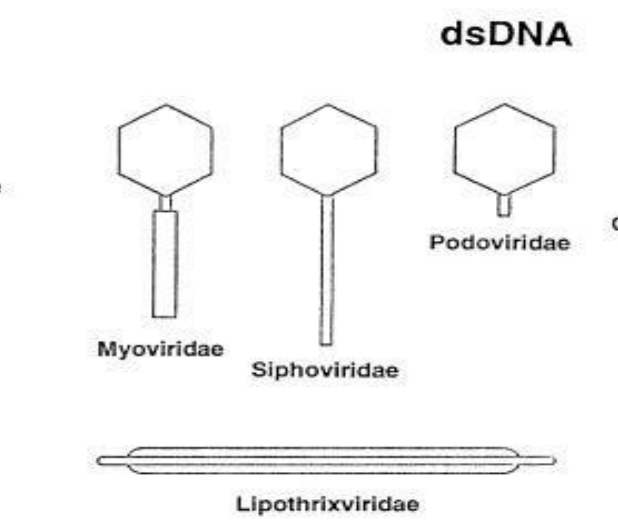
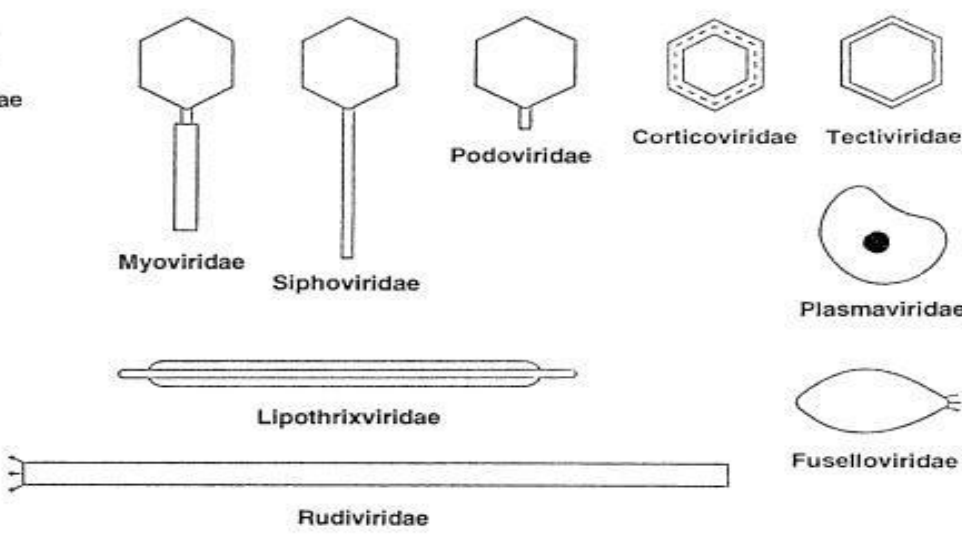

Plasmaviridae

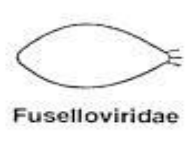

SSRNA

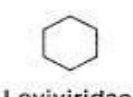

dsRNA

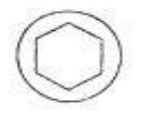

Fig. 2: Bacteriophages morphotypes (Ackermann and Dubow, 1987).

\section{Life cycle of bacteriophages}

Phages can infect bacterial cells and release by large number after infection and replication inside the host cells (Sime-Ngando, 2014). The main proceedings of infection are shown in Fig. 3. Phages are grouped as either temperate or virulent (lytic) according to the type of replication. In lytic cycle, once the cell has infected with a phage, the phage starts to direct the cell towards formation of new particles. Once the new phages have been formed, the lytic activity using some lytic enzymes including endolysins and holins occurs to release the new progeny (Sime-Ngando, 2014).

In case of lysogenic cycle, the temperate phage has the capability to integrate its DNA into the host genome to be replicated with the host genome and transmitted by daughter cells, which is called prophage. The prophage stays in dormant state until the induction of lytic cycle by the surrounding stress such as chemical agents and ultraviolet radiation. pseudolysogenic and chronic infections are also observed in the cycles (Weinbauer, 2004). 


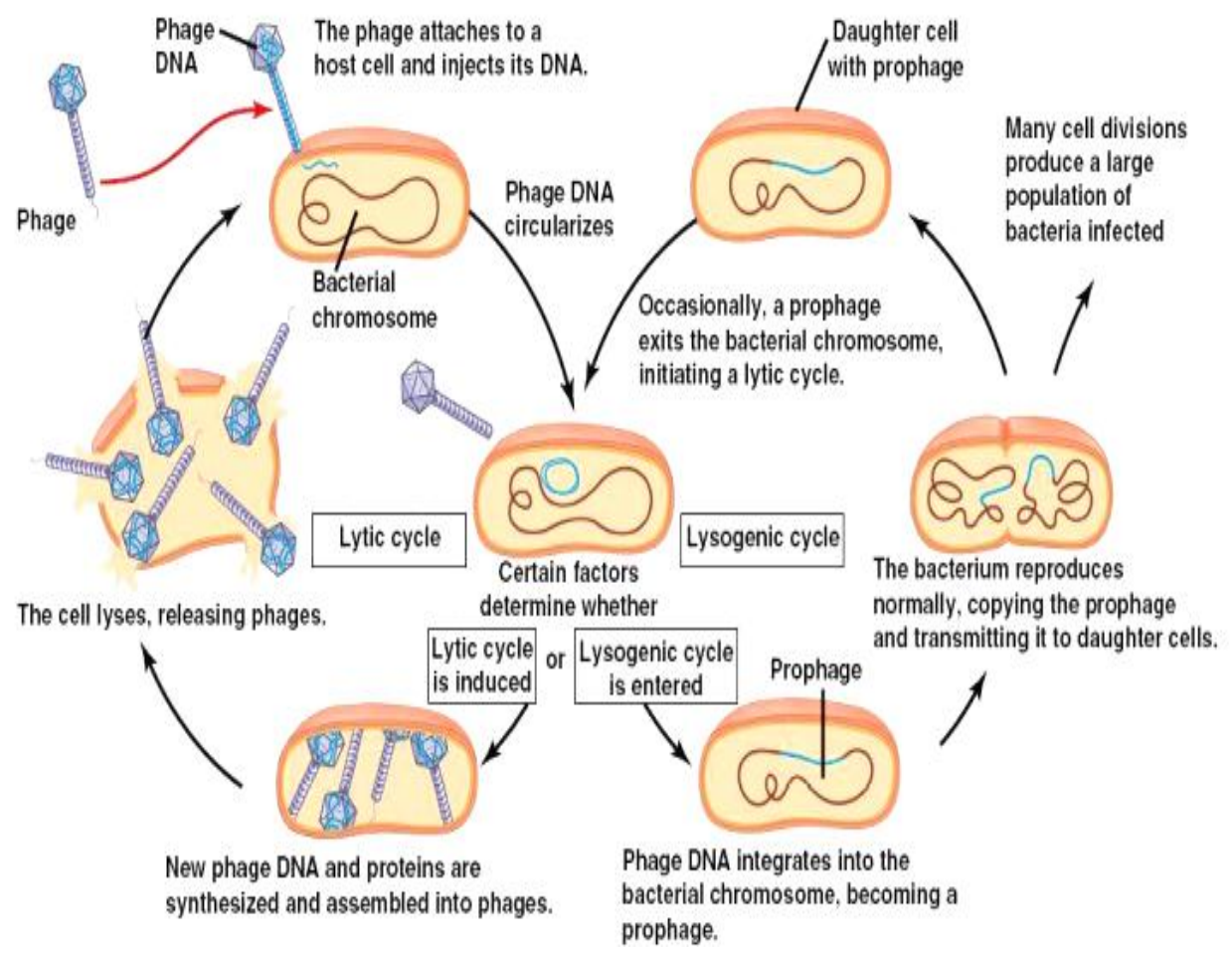

Fig. 3: Main steps of lytic and lysogenic phage infection cycles (Pal, 2015).

\section{Lytic activity using bacteriolytic enzymes (Enzybiotics)}

Bacteriolytic enzymes produced by bacteriophages are known as Enzybiotics . However, at present the word includes all enzymes with ability to kill bacterial pathogens (Keary et al., 2013). Activity of Enzybiotics against Gram positive bacteria is illustrated in Fig. 4.

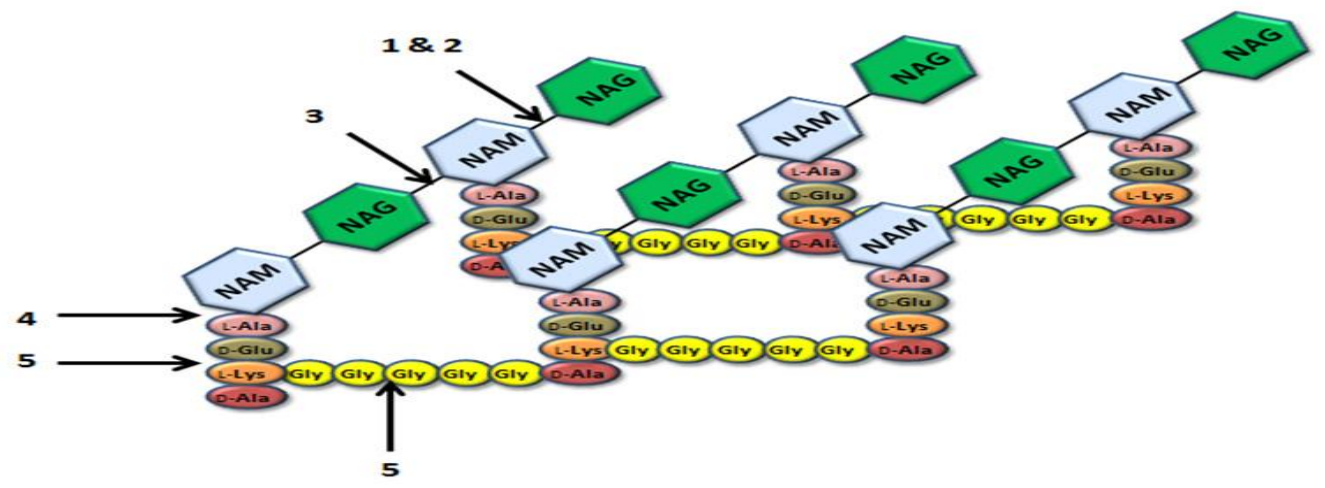

Fig. 4: The structure of Staphylococcus aureus peptidoglycan with the cleavage site of the five main types of enzymatic domain found in endolysins: 1) Nacetyl$\beta$-D-muramidase (lysozymes), 2) lytic transglycosylase, 3) $\mathrm{N}$-acetyl- $\beta$ Dglucosaminidase, 4) NacetylmuramoylL-alanine amidases, 5) Endopeptidase. NAM: N-acetylmuramic acid. NAG: Nacetylglucosam (Keary et al., 2013). 


\section{Bacteriophages in the marine environment}

Most of the works are restricted to bacterial viruses of terrestrial origin. Marine bacteriophages have received only little attention (Sekar and Kandasamy, 2013). Bacterial viruses or bacteriophages in seawater were first observed in the first half of the last century (Kriss and Rukina, 1947). Phages have been reported to kill 20-40\% of marine bacteria every day (Suttle, 2005). Hence, they are considered as the main player in ecological systems and bacterial evolution. They also have an important role in biogeochemical cycles (phosphorous, nitrogen and carbon cycles). Thus study of marine phages helped in understanding the regulation mechanism of aquatic systems (SimeNgando, 2014). Overall, studies concerning ecology of marine bacteriophages are roots of novel information about evolution and biodiversity of living organisms, and the functioning of ecosystem. Phage-host interaction in the marine environment has an important role on evolution and mortality of marine microbes (Garin-Fernandez et al., 2018) (Fig. 5).

\section{Abundance and distribution of bacteriophages in the marine environment}

Phages are prevalent in all marine environments representing the highest abundant structure and are regarded as the greatest reservoir of diversity on the earth (SimeNgando, 2014), millions of phages exist in $1 \mathrm{ml}$ of seawater (Bergh et al., 1989). Different studies showed that the abundance of phages in the marine environment is approximately 10-fold more than bacteria and variation in the bacteria-phage interaction can be observed (Wigington et al., 2016), also phage diversity may be high even at small scales (Flaviani et al., 2017). It was reported that phage abundances in sediments is higher than that in the water column by 10-1000 times (Danovaro et al., 2008).

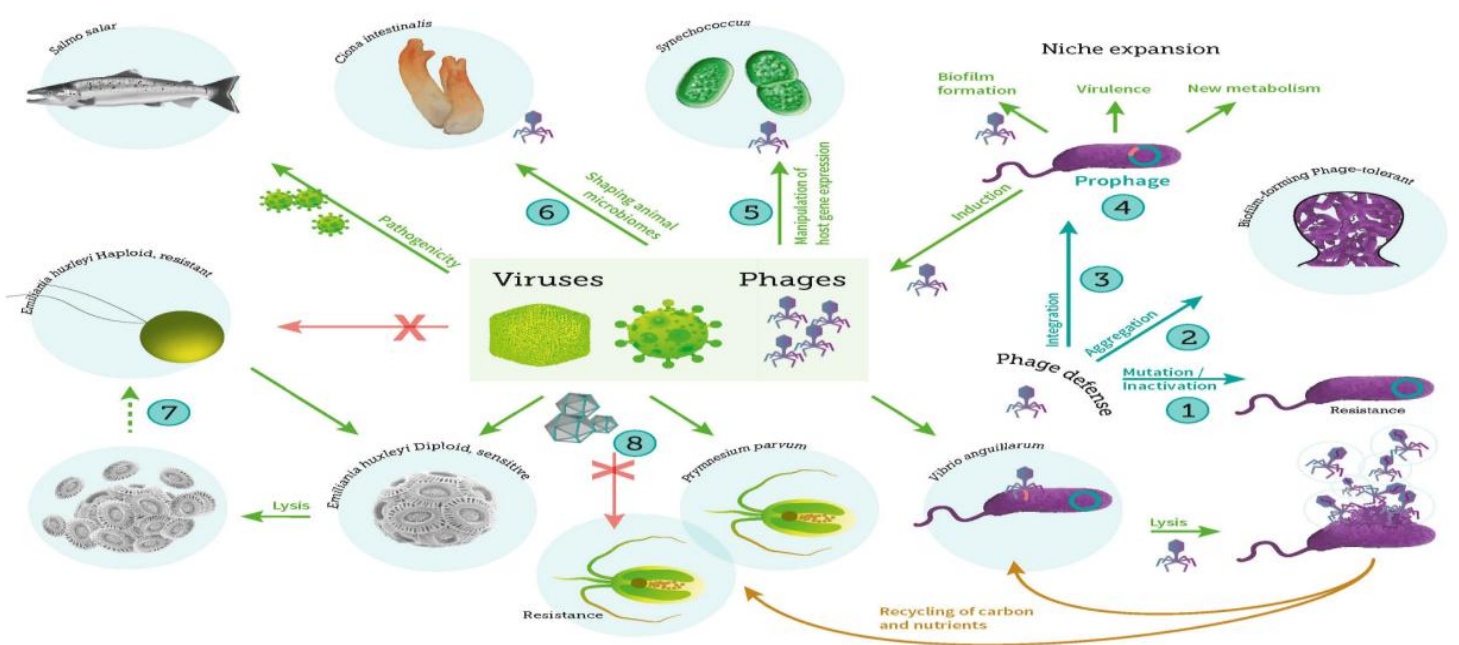

Fig. 5: Schematic overview of important phage-host interactions in the marine ecosystem (Middelboe and Brussaard, 2017). 


\section{Ecological role of bacteriophages in the marine environment}

\section{Effect of bacteriophages on microbial community and diversity}

Mortality of bacterial cells by phages is the major factor controlling production and diversity of microbial community in marine systems. The majority of phages is not pathogens and has an effect on the release and reservation of organic matter in the pelagic universe. According to the fact of recombination between host genes and phage and also spread of phage-encoded biological functions, phage populations are important for storage of genes that participate to division of microbes in marine habitat. Moreover, they represent an important tool for evolution of genes in natural habitat, and could play an essential role in the genetic diversity of microbial populations (Sime-Ngando, 2014). Population of phages also contribute to classification of microbial species due to gene transfer by different mechanisms including transduction, transformation and conjugation (Fig. 6), which in turn affect gene evolution in the marine ecosystems (Sime-Ngando, 2014).

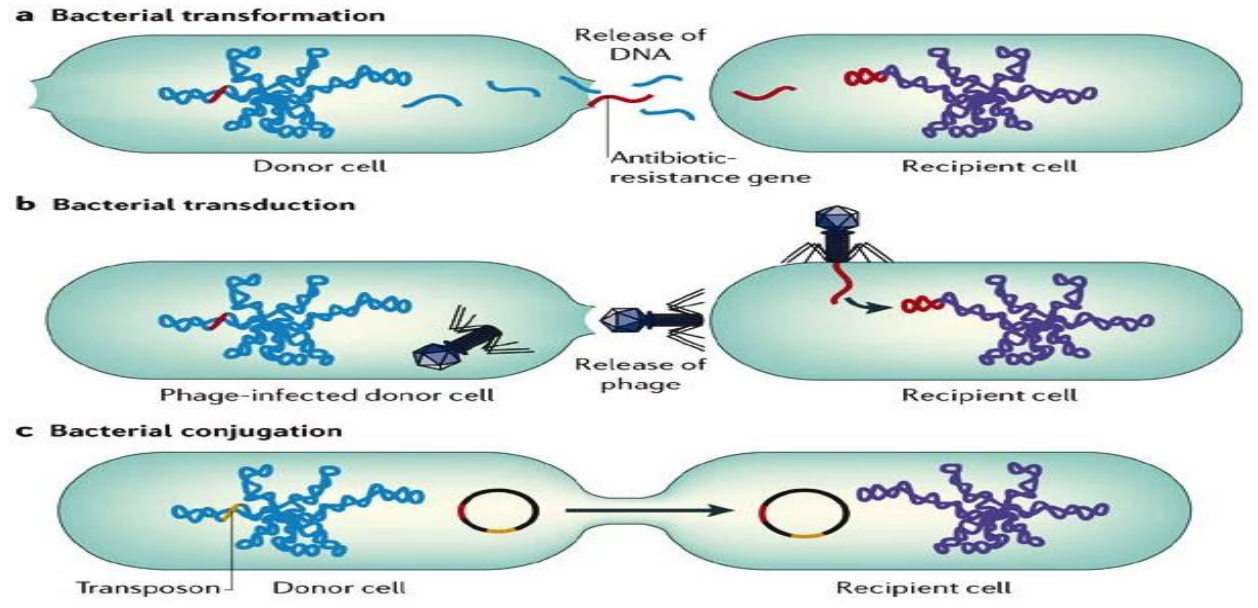

Fig. 6: Types of gene transfer: (a) bacterial transformation, (b) bacterial transduction and (c) bacterial conjugation (https://vignette.wikia.nocookie.net).

Transduction is a random action and has an effect on populations and transfer of genetic material in marine environment. It was suggested that about 1024 genes are transferred from phages to hosts by transduction each year (Rohwer and Thurber, 2009). Several helpful functional and metabolic genes were detected in the genomes of phage, representing a mutual benefit to phage and host that could be spread to other hosts through transfer of genes. These genes can participate to functional characteristics of the host such as virulence. They can also induce the formation of bacterial biofilm (Gödeke et al., 2011). 
An interesting example is the photosynthetic genes exist in the genomes of cyanophage, which can be used to preserve the function of photosynthesis in hosts, and can be moved between hosts (Lindell et al., 2005). It was reported that genes originating from phages cause the achievement of about 10\% of global photosynthesis (Rohwer and Thurber, 2009).

The release of host components after lysis by phages can alter the bioavailability and composition of organic substances and nutrients, which is considered as key player and affects the community structure and microbial composition. These levels are affected by host availability (density and activity), temperature, growth rate of the host cells, solar radiations and anoxia. This manner enhances the coexistenc within communities or prevent dominance of species which can determine the diversity and community structure (Pradeep Ram et al., 2010). Understanding of the interaction between host and phage is necessary to predict the effect of environment on phage-driven operations in sea. Important phage host interactions occur in the marine ecosystem are shown in Fig. 7.

\section{Effect on biogeochemical cycling}

Bacteriophages have great direct or indirect effects on the cycling of elements due to killing microbial hosts such as archae, bacteria, cyanobacteria, which dominate in pelagic systems, and are the main partners in the food web. They have a great direct or indirect effect on cycling of carbon, nitrogen, phosphorus and other elements, which are essential in the food web (Fuhrman, 1999). It was reported that approximately $10^{8}-10^{9}$ tons of carbon per day is released from the living biological aggregation and resulted from about 1029 viral infection events per day (Suttle, 2007). It was estimated that 25\% of the carbon fixed through photosynthesis cycles is through the viral shunt (Fig. 8, 9). Thus lytic activity of phages is potent producer of nutrients to primary producers leading to increases of organic matter (DOM) retention time and respiration in the water column A modeling exercise proposed that lysis of $50 \%$ of bacterial population caused $27 \%$ increase in microbial respiration (Fuhrman, 1999) and nutrient retention by decreasing of organic matter sedimentation (Ankrah et al., 2014). 


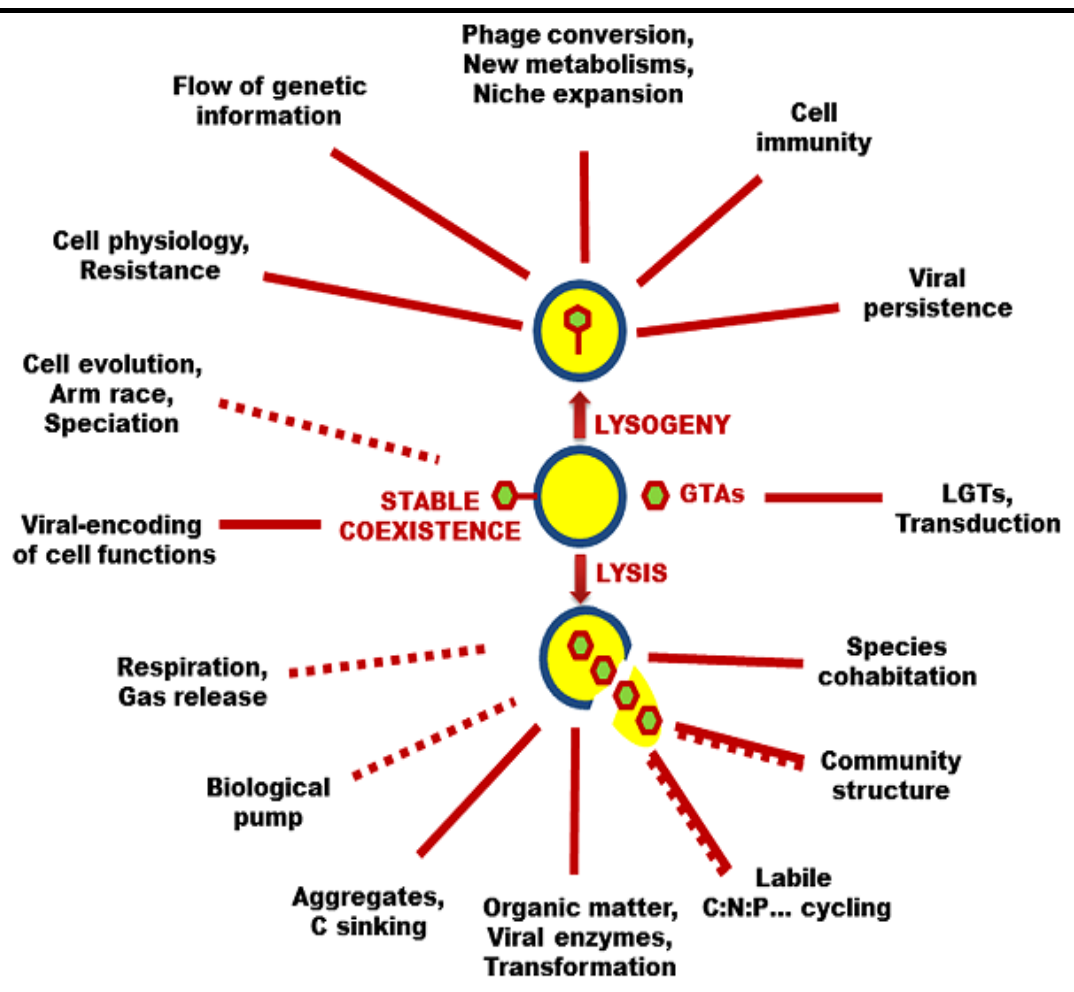

Fig. 7: Phage-microbe interactions (Sime- Ngando, 2014)

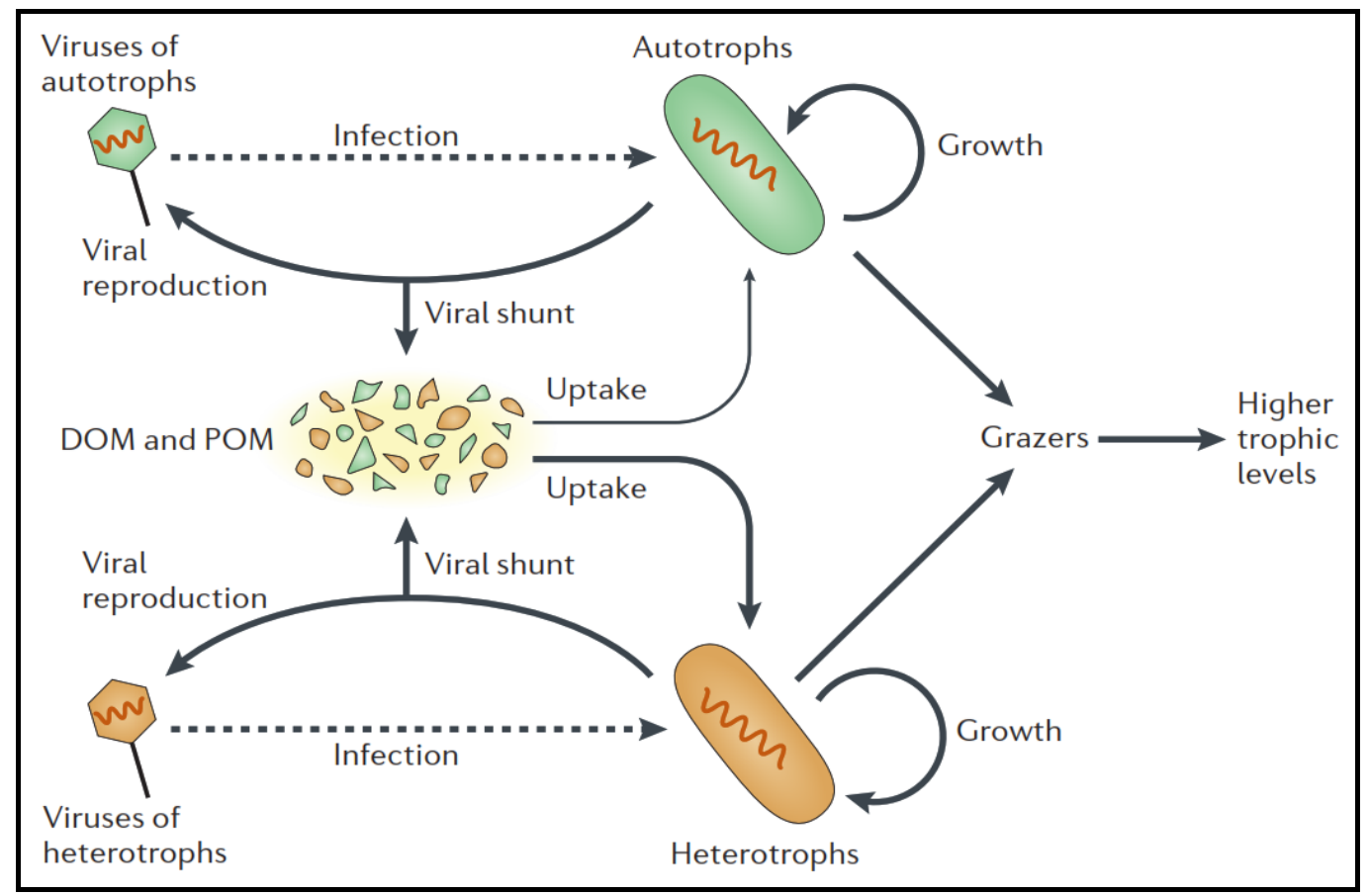

Fig. 8: Schematic of the viral shunt (Jover et al., 2014). 


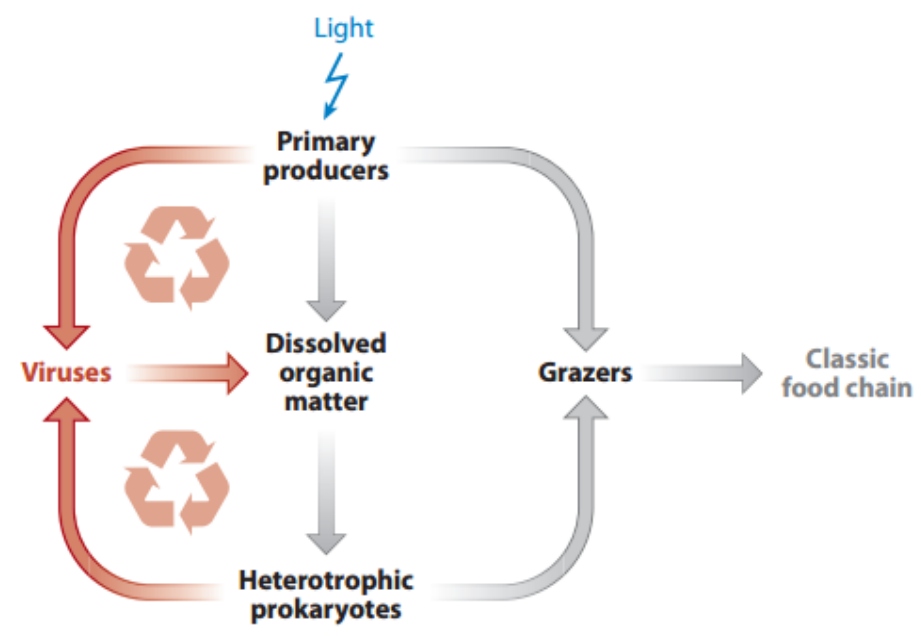

Fig. 9: Simple diagram of the marine microbial food web, with the viral shunt highlighted in red colour (Breitbart, 2012).

\section{Some environmental applications of bacteriophages}

\section{Indication of faecal pollution in the marine environment}

Disposal of wastewater in the marine environment causes serious health problems, because wastewater treatment methods remove only the suspended solids with some degree of pathogen elimination. The fast, easy, cost effective enumeration, detection of bacteriophages and the persistance of them in water in addition to their high concentration exist in areas contaminated with faecal remains encourage the use of them as indicators of water quality.

Dias et al. (2018) suggested the use of somatic phages as indicator of enteric viral pathogens than the current faecal coliform and that these phages will play a vital role in future health care planning.

\section{Detection of pathogenic bacteria}

The immobilized Landscape phage 1G40 was applied for detection of $\beta$ galactosidase from E. coli (Nanduri et al., 2007). The immobilized filamentous phage on piezoelectric transducer was also used for the detection of Salmonella typhimurium (Olsen et al., 2006).

Filamentous bacteriophage was used to detect $S$. typhimurium and spores of Bacillus anthracis in water and fat free milk (Lakshmanan et al., 2007 a, b; Petrenko, 2008). It was observed that the frequency changes of resonance with time is related to mass of spores on the sensor. The captured spore cells were detected using scanning electron microscopy (SEM) (Fig. 11) 

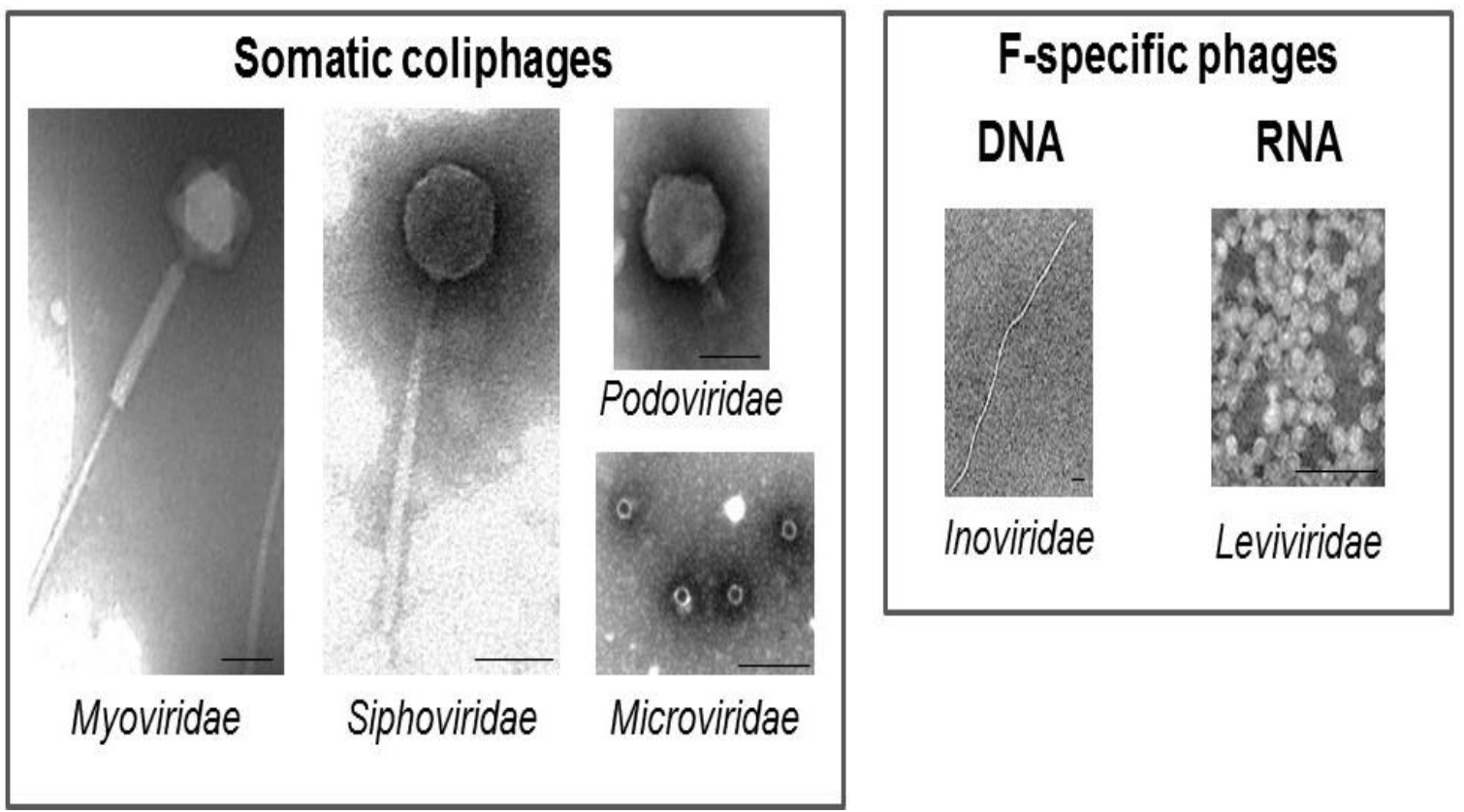

Fig. 10: The most common morphological types in somatic coliphages (a) and Fspecific phages (b) (Jofre et al., 2016).
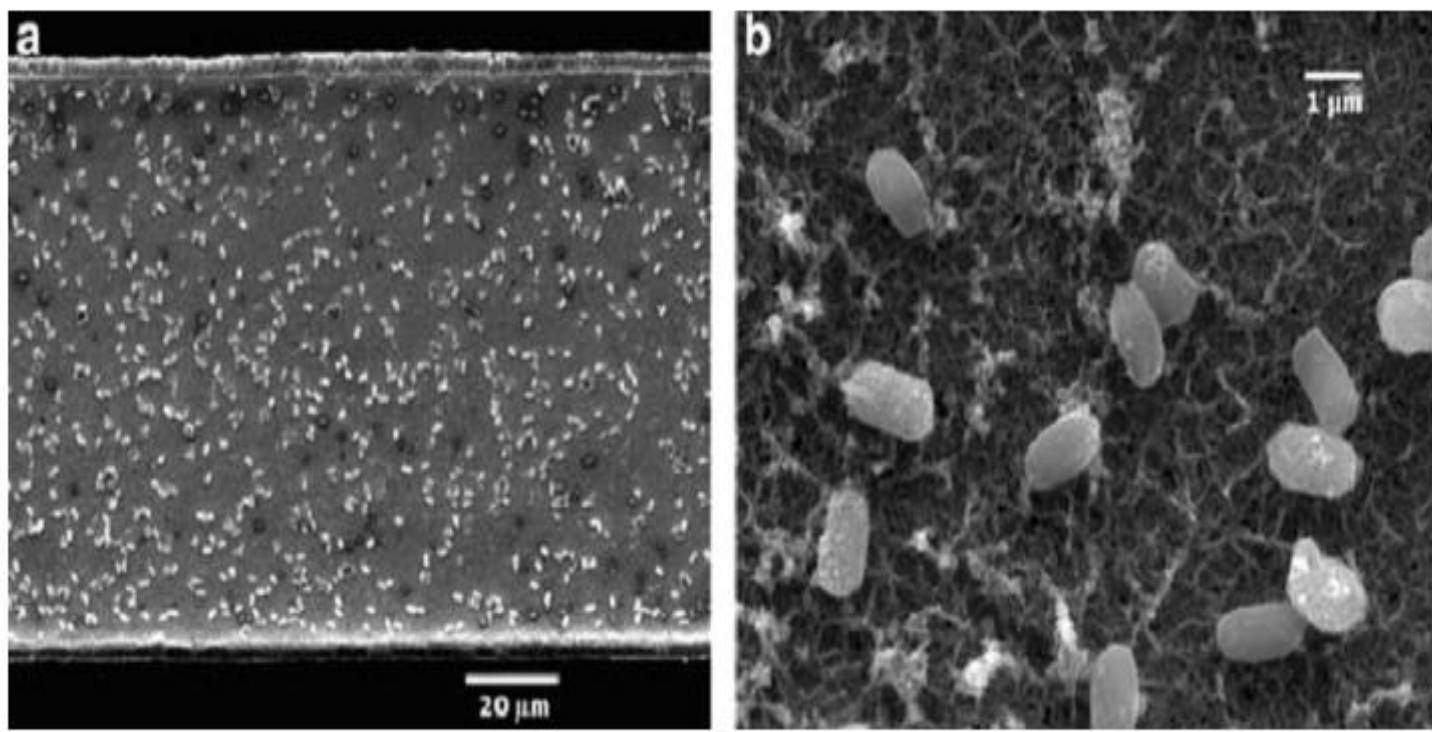

Fig. 11: SEM image of sensor coated with filamentous phage (a) and attachment of the spores to the phage (b). (Johnson et al., 2008). 
The platforms that have leveraged phage-based probes have used intact bacteriophage particles as the recognition element, and have effectively detected some pathogens in food (Fig. 12).

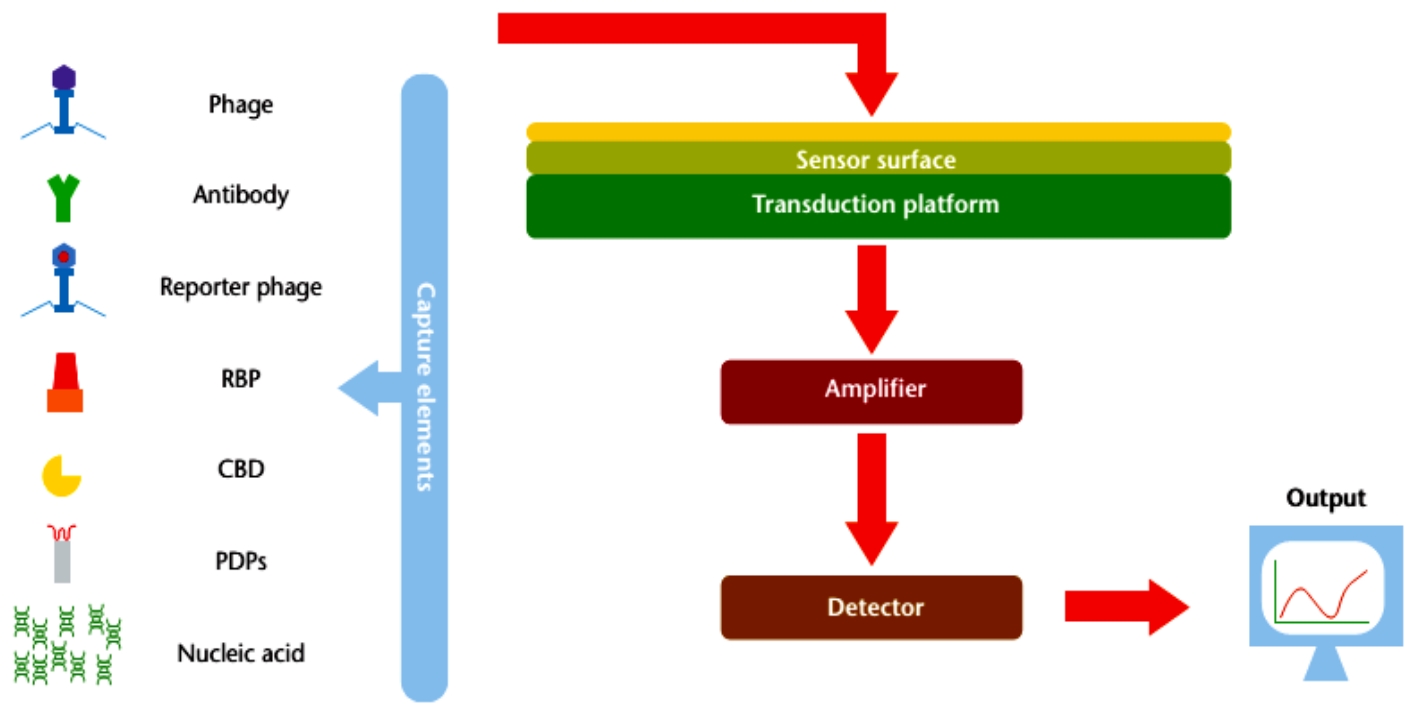

Fig. 12: The components of a biosensor showing various biorecognition elements that may be attached to the surface (Gutiérrez et al., 2019).

\section{Phage therapy in aquaculture}

Phage therapy, the use of bacteriophage viruses to treat bacterial infections, has existed for more than a hundred years (Brives and Pourraz, 2020). Success of phage therapy against bacterial pathogens depends on different factors such as physico-chemical factors ( $\mathrm{pH}$, temperature...), the bacteriophage/bacteria ratio and resistance to phage or phage neutralization. The most effective parameters are the initial dose of phage, the burst size, latent period and phage adsorption rate (Payne and Jansen, 2001). Different phage products have been used in human medicine, agriculture, the food industry and has proven efficacy as a biocontrol agent towards aquaculture disease (Ninawe et al. 2020). A range of products have been approved by the Food and Drug Administration (FDA) (Ly-Chatain, 2014).

\subsection{Biocontrol of common bacterial pathogens in aquaculture}

\subsubsection{Vibrio spp.}

The fast development of industry over the the past decades led to occurrence of vibriosis in aquaculture (Kalatzis et al., 2018). Clinical signs of vibriosis (Fig. 13) include hemorrhages on the skin, unusual swimming behavior, loss of appetite close to the water surface, increased mucus secretion, petechial hemorrhages in the muscle, anemia and intestinal necrosis. Vibrio spp. such as V. parahaemolyticus, V. campbellii 
and $V$. harveyi, are recognized as the causative agents of luminous vibriosis in shrimp farm (Kalatzis et al., 2018).

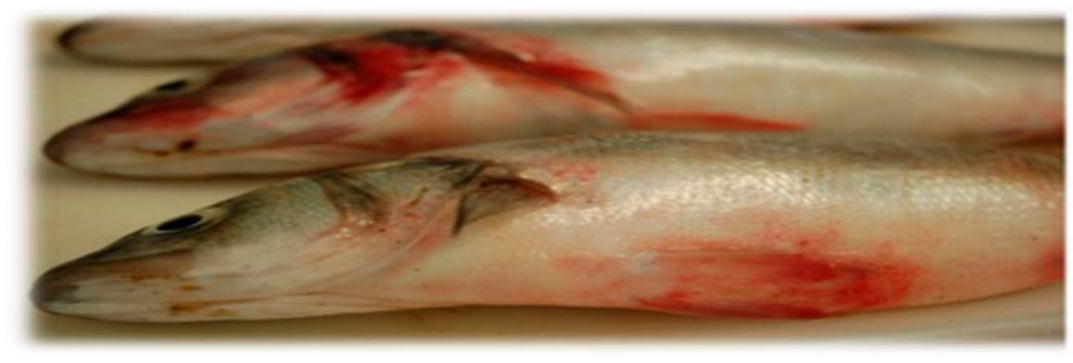

Fig. 13: Symptoms of vibriosis in cultured European seabass (Kalatzis et al., 2018).

A potential of bacteriophages to control pathogenic $V$. harveyi in hatchery setting was reported by Kumar et al. (2006). Promising results have been shown in sea cucumber (Zhang et al., 2016). Three phages (PVS-1, PVS-2 and PVS-3) were tested against $V$. splendidus. Different diets were prepared, where bacteriophages were added separately to each diet and another diet was prepared with a cocktail of the tested bacteriophages. Another set of diets supplemented with antibiotics were also prepared in addition to the un supplemented diets (control). The diets were given daily to the sea cucumbers for 60 days. Then the sea cucumber were immersed in seawater containing $V$. splendidus for two days, followed by monitoring the survival rates for ten days. The survival was $82 \%$ for diets containing cocktail of phages, $50 \%-65 \%$ for the diets supplemented with individual phages and only $18 \%$ for the control. In the same investigation, injection of healthy sea cucumbers with $V$. splendidus was carried out, while sterile sea water was used to inject the control group. Subsequent injection of the infected group with phage cocktail was done and the rates of survival were checked for ten days. It was noticed that the survival was $80 \%$ for the treated group, while it was only $20 \%$ in case of untreated group. Hassan (2017) isolated some vibriophages from seawater samples collected from Alexandria seashore, Egypt. Four phages namely P10, P16, P17 and P20 were chosen and tested for host specificity. It was reported that P17 exhibited broad spectrum of antibacterial activity and was stable at $\mathrm{pH}$. Phage host interaction was studied showing that P17 had burst size (100 PFU per cell) and latent period $(10 \mathrm{~min})$. The study also indicated the promising effect of P17 in control of Vibrio spp. invading aquaria of Artemia salina.

\subsubsection{Aeromonas spp.}

Aeromonas hydrophila is a motile rod, facultatively anaerobic Gram-negative bacteria. It causes hemorrhagic septicemia and fin and tail rot. The symptoms appear as lesions leading to loss of scales and fin erosion; abscesses and ulcers; gills and vents hemorrhaging. Silva et al. (2016) tested the efficiency of phage therapy to eliminate $A$. salmonicida, the causative of furunculosis, resulting in high morbidity and mortality of Solea senegalensis juveniles. They isolated a new phage and investigated its ability to 
eliminate A. salmonicida in infected juveniles of Solea senegalensis. Results revealed the absence of mortality after $72 \mathrm{~h}$ in case of fish treated with phages.

Hassan et al. (2018) isolated four Aeromonas phages from seawater samples collected from Alexandria, Egypt. They studied the molecular characterization of them and optimization of culture conditions to improve the antibacterial activity of the most promising phage isolate (AP2) against A. hydrophila. The study also evaluated the potential of marine phages for therapy of motile Aeromonas septicemia caused by $A$. hydrophila in Nile tilapia (Oreochromis niloticus) showing 94\% elimination of $A$. hydrophila in aquaria of Nile tilapia infected with A. hydrophila compared to aquaria without phage treatment. Morphological and histological examination of the tested liver tissues are shown in Fig. 14.
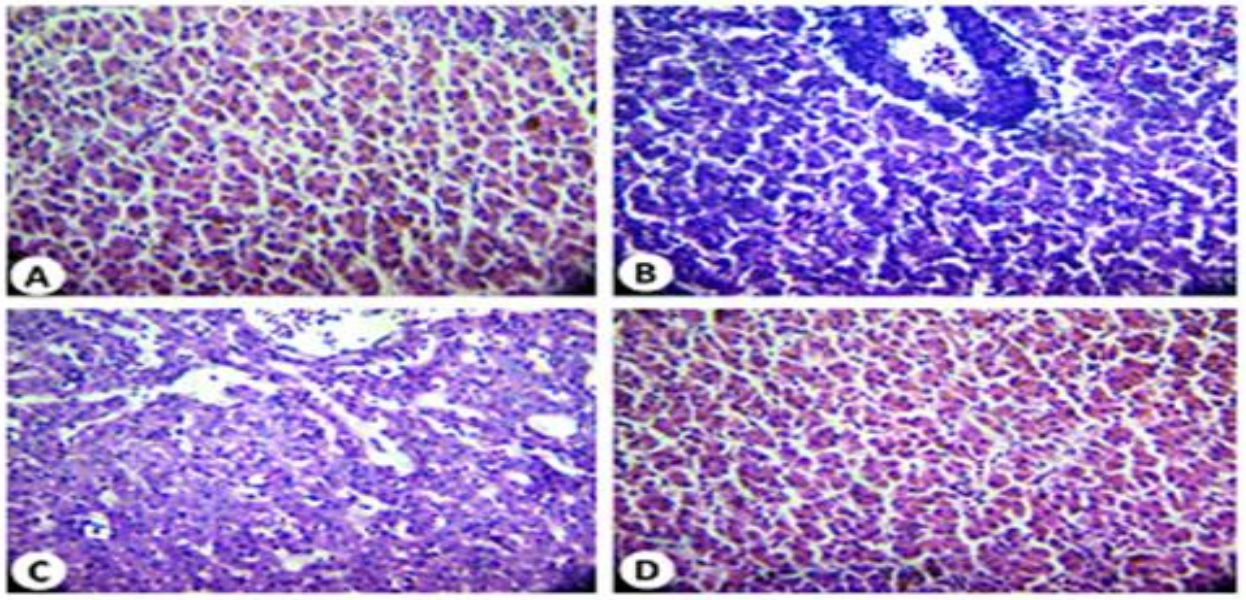

Fig. 14: Histopathological alterations of Oreochromis niloticus liver: (A): Normal liver tissue (control); (B): infected liver tissue showing disruption of the normal hepatic cord-like pattern, a great reduction in number and size of hepatocytes, (C): O.niloticus liver tissue treated with 1:1 (phage AP2: A. hydrophila) and (D) O.niloticus liver tissue treated with 1:2 (phage AP2: A. hydrophila) (D) (H\&E: X, 400). Hassan et al. (2018).

\subsubsection{Pseudomonas spp.}

Pseudomonas sp. causes hemorrhagic ascites in ayu fish (Plecoglossus altivelis). The clinical signs of infection appear as bloody ascites fluid and lesions in the spleen, liver, kidney, intestines, gills and heart (Austin and Austin, 2012). Park et al. (2000) reported the ability of isolated phages belonging to Podoviridae (designated PPpW-4) and Myoviridae (designated PPpW-3) to heal ulcerative lesions caused by $P$. aeruginosa. and the mortality reached $22.5 \%$ compared to $65.0 \%$ mortality. 


\subsubsection{Streptococcus spp.}

Streptococcus sp. is a Gram-positive bacterium that causes streptococcosis (Figure 15) in fish and is responsible for $30-50 \%$ of the deaths in some fish. Matsuoka et al. (2007) carried out experiments on the Japanese flounder (Paralichthys olivaceus) by injection of the bacterial pathogen Streptococcus iniae and subsequent injection of phage isolates. They showed that less mortality of the fish was detected after 15 days.

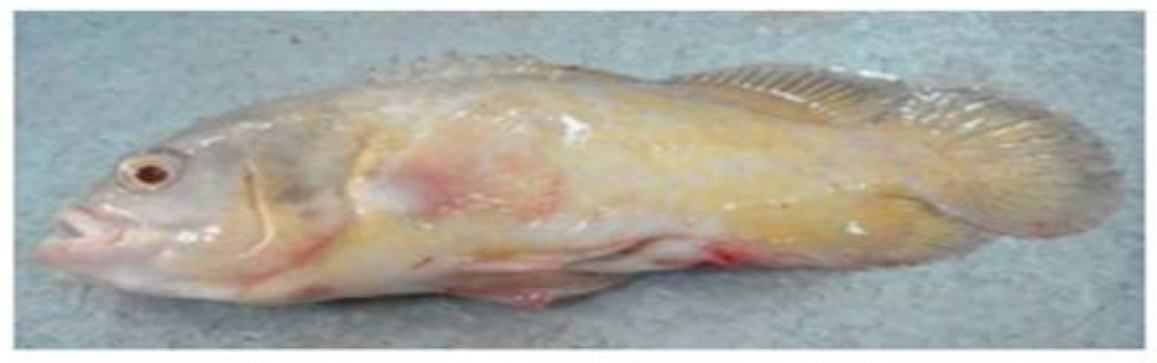

Fig. 15: Symptoms of streptococcosis: exophthalmia hemorrhages around the gill plate, base of fins (Tukmechi et al., 1999).

\subsubsection{Edwardsiella spp.}

Edwardsiella ictaluri and E. tarda are the major species infecting fish. The infected fish suffers from lesions on their skin, loss of pigmentation, opacity of the eyes, swelling of the abdominal and mucus secretion (Fig. 16). Hsu et al. (2000) indicated the ability of the isolated phages to control E.tarda by about $1.5 \log$ after $8 \mathrm{~h}$ of treatment.

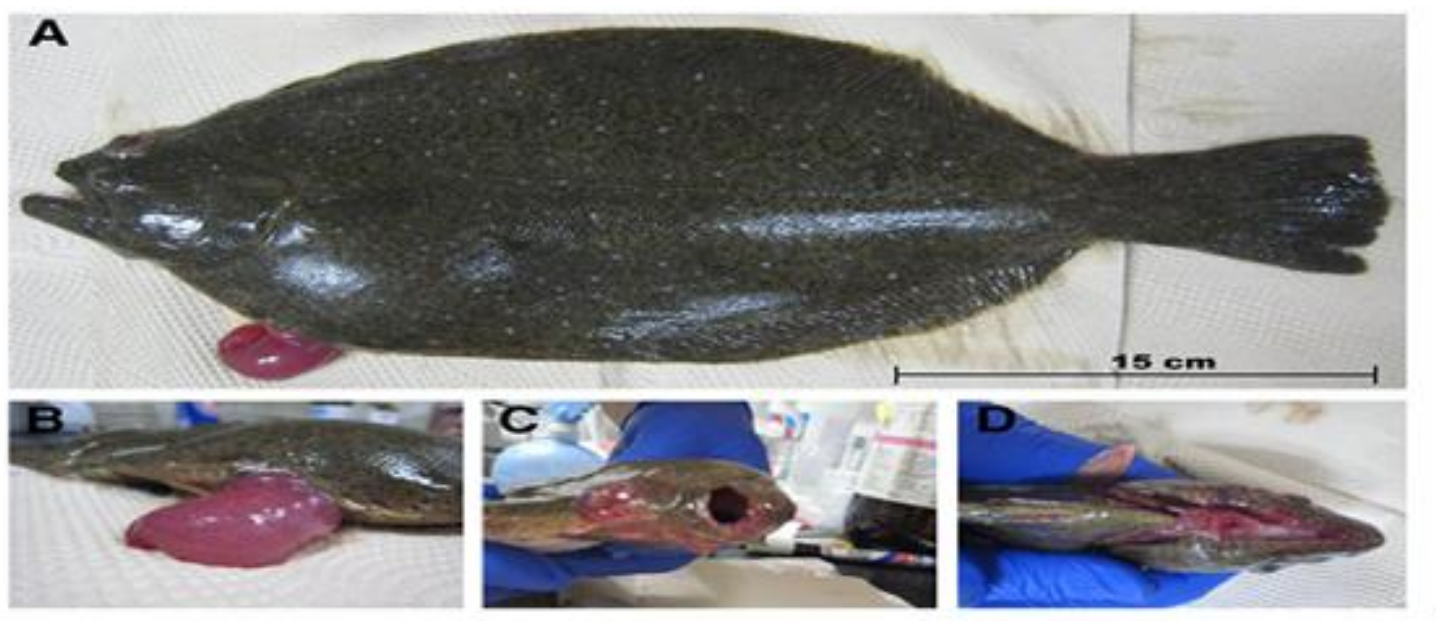

Fig. 16: External signs of olive flounder infected with Edwardsiella tarda. A: External lesions of diseased fish. B: Abdominal distension and rectal hernia. C: Exophthalmia and opacity of the eye. D: Peripheral hyperemia in mandible lesion (Park et al., 2012). 


\subsubsection{Escherichia coli}

E.coli is Gram negative bacteria. Pathogenic bacteria such as E.coli can be transferd to oysters through handling, rising with water and inappropriate storage (Carrasco et al., 2012) causing faecal contamination and at least six types of intestinal infections. Le et al. (2018b) reported the efficiency of bacteriophage cocktail in eliminating $E$. coli strains in the edible oyster leading to protection of consumer health. of haemorrhagic E. coli $\mathrm{O} 157: \mathrm{H} 7$ after 1 h of treatment.

\subsubsection{Phage therapy of coral diseases}

Coral diseases cause great harm to coral reefs throughout the world (Harvell $\boldsymbol{e t}$ al., 2002). Microorganisms are responsible for these diseases (Rosenberg and BenHaim, 2002). In a study by Efrony et al. (2007), lytic phages specific to bacterial pathogens that are responsible for diseases of coral were tested for phage therapy. The investigation of phage therapy of the infected coral demonstrated the success of the specific phages in controlling diseases caused by bacterial infection. The data concluded that the bacteriophages can bind to the bacterial pathogens on coral surface and they multiply with lytic activity. These phages can be kept connected with the coral and prevent the other bacterial infections. These results suggested the potential of phage therapy to control the prevalence of coral diseases (Efrony et al., 2007). Photographs and electron micrographs of diseased and healthy corals, phages and bacterial pathogens used in the study are presented in Fig. 17. 

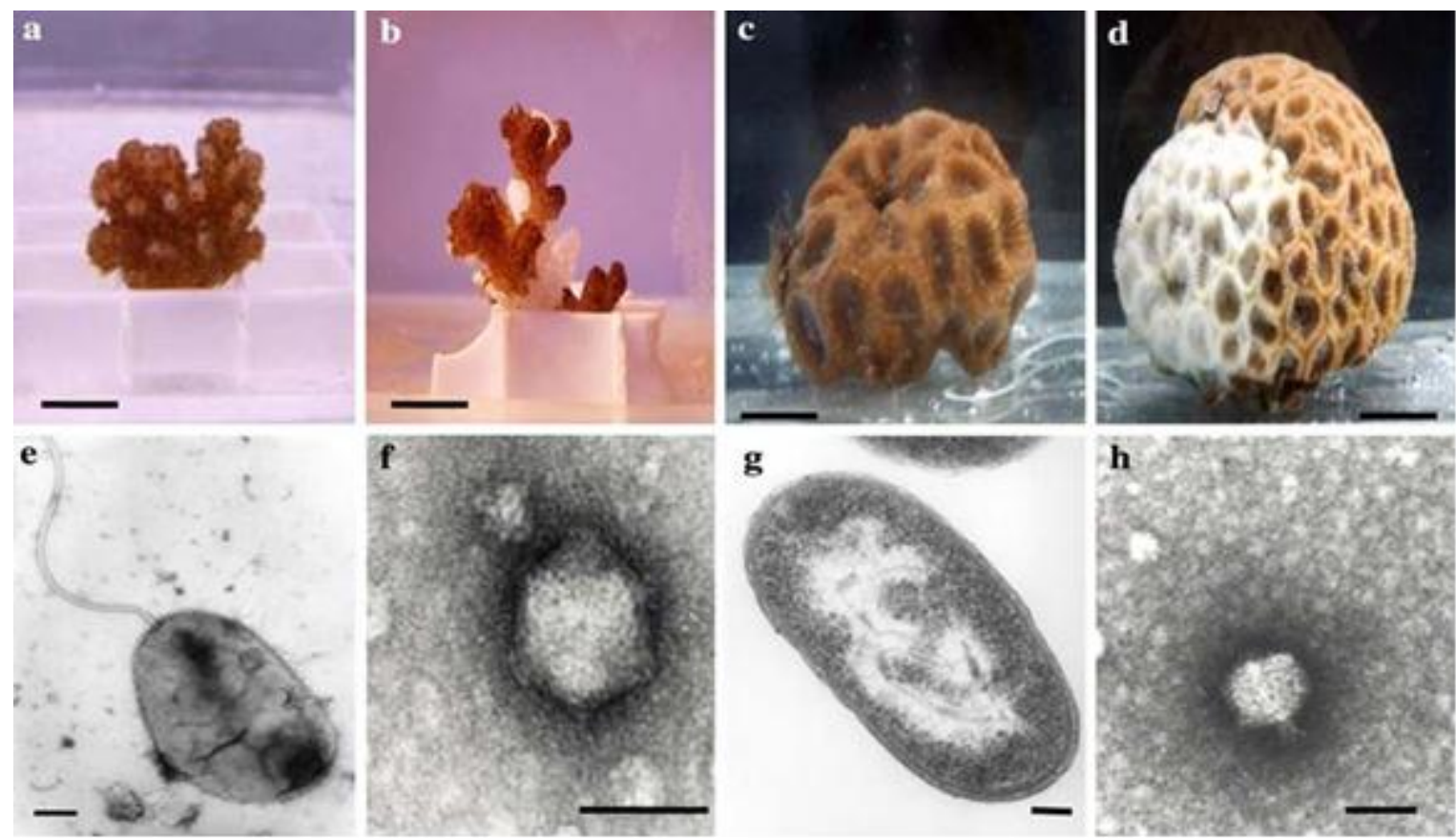

Fig. 17: Images showing corals, bacterial pathogens and bacteriophages a) Healthy, b) partially lyzed Pocillopora damicornis, (c) healthy and d) partially lyzed Favia favus. Negatively stained electron micrographs of Vibrio coralliilyticus (e), phage YB2 (f), a thin section of Thalassomonas loyaeana (g) and phage BA3 (h) (Efrony et al., 2007).

\section{CONCLUSION}

Bacteriophages are viruses that can exist in the bacterial host. Specific phage populations differ over space and time. Moreover, bacteriophages contribute to horizontal gene transfer, evolution of bacterial species and conservation of ecological balance. Bacterial contamination in aquacultue causes great mortalities. The recent developments and future visions in the aquaculture sector is phage therapy. Administration of bacteriophage cocktails is the best appropriate application approach if large number of infected fish need to be manipulated. According to the earlier studied data, this approach introduces the regulation of severe bacterial infection in fish farming, which avoids hazard consuming of antibiotics and chemicals in aquaculture.

\section{REFERENCES}

Abdelkader, K.; Gerstmans, H.; Saafan, A.; Dishisha, T. and Briers, Y. (2019). The preclinical and clinical progress of bacteriophages and their lytic enzymes: The parts are easier than the whole. Viruses, 11: 1-16.

Ackermann, H.W. (2007). 5500 Phages examined in the electron microscope. Arch. Virol., 152(2): 227-243. 
Ackermann, H.W. and Dubow, M.S. (1987). General properties of tailed phages. In : Viruses of Prokaryotes. CRC Press, Boca Raton, pp 13-47.

Ankrah, N.W.D.; May, A.L.; Middleton, J.L.; Jones, D.R.; Hadden, M.K. and Gooding, J.R. (2014). Phage infection of an environmentally relevant marine bacterium alters host metabolism and lysate composition. ISME J., 8: 10891110.

Austin, B. and Austin, D.A (2012). Bacterial Fish Pathogens. $5^{\text {th }}$ ed. Springer, New York.

Bair, C.L. and Black, L.W. (2007). A type IV modification dependent restriction nuclease that targets glucosylated hydroxymethyl cytosine modified DNAs. J. Mol. Biol., 366: 768-778.

Bair, C.L.; Rifat, D. and Black, L.W. (2007). Exclusion of glucosylhydroxymethylcytosine DNA containing bacteriophages is overcome by the injected protein inhibitor IPI. J. Mol. Biol., 366: 779-789.

Baloch, Z.; Aslam, B.; Wei, W. and Arshadm, M. (2018). Antibiotic resistance: a rundown of a global crisis. Infect. Drug Resist., 11: 1-14.

Bergh, O.; Borsheim, K.Y.; Bratbak, G. and Heldal, M. (1989). High abundance of viruses found in aquatic environments. Nature, 340: 467-468.

Breitbart, M.; Bonnain, C.; Malki, K. and Natalie, A. (2018). Sawaya Phage puppet masters of the marine microbial realm. Nat. Microbial., 3: 754-766.

Breitbart, M. (2012). Marine Viruses: Truth or Dare. Annu. Rev. Mar. Sci., 4: 425-448.

Brives, C. and Pourraz, J. (2020). Phage therapy as a potential solution in the fight against AMR: obstacles and possible futures Palgrave Commun. https://doi.org/10.1057/s41599-020-0478-4.

Carrasco, E.; Morales-Rueda, A. and García-Gimeno, R.M. (2012). Cross contamination and recontamination by Salmonella in foods: a review. Food. Res. Int., 45(2): 545-556.

ombet, J.; Sime-Ngando, T.; Cauchie, H.M.; Fonty, G.; Hoffmann, L. and Demeure, G. (2006). Depth-related gradients of viral activity in Lake Pavin. Appl. Environ. Microbiol., 72: 4440-4445.

D'Herelle, F. (1917). Sur un microbe invisible antagoniste des bacilles dysentériques. C. R .Acad Sci (Paris). 165: 373-375. 


\section{Danovaro, R.; Dell'Anno, A.; Corinaldesi, C.; Magagnini, M.; Noble, R.,} Tamburini; C. and Weinbauer, M. (2008). Major viral impact on the functioning of benthic deep-sea ecosystems. Nature, 454: 1084-1087.

\section{Destoumieux-Garzon, D; Duquesne, S.; Peduzzi, J.; Goulard, C.; Desmadril,} M.; Letellier, L.; Rebuffat, S. and Boulanger, P. (2005). The ironsiderophore transporter FhuA is the receptor for the antimicrobial peptide microcin J25: role of the microcin Val11-Pro16ß-hairpin region in the recognition mechanism. Biochem. J., 389: 869-876.

Dias, E.; Ebdon, J. and Taylor, H. (2018). The application of bacteriophages as novel indicators of viral pathogens in wastewater treatment systems. Water Res., 129 (1): $172-179$.

Efrony, R.; Loya, Y.; Bacharach, E. and Rosenberg, E. (2007). Phage therapy of coral disease. Coral Reefs 26: 7-13.

Flaviani, F.; Schroeder, D.C.; Balestreri, C.; Schroeder, J.L.; Moore, K.; Paszkiewicz, K.; Pfaff, M.C. and Rybicki, E.P. (2017). A pelagic microbiome (Viruses to protists) from a small cup of seawater. Viruses, 9(3): 1-19.

Fuhrman, J. A. (1999). Marine viruses and their biogeochemical and ecological effects. Nature, 399: 541-548.

Garin-Fernandez, A.; Pereira-Flores, E.; OliverGlöckner, F. and Wichels, A. (2018). The North Sea goesviral: Occurrence and distribution of north Sea bacteriophages. Mar Genomics., 41: 31-41.

Gödeke, J.; Paul, K.; Lassak, J. and Thormann, K.M. (2011). Phage-induced lysis enhances biofilm formation in Shewanella oneidensis MR-1. ISME J., 5: 613626.

Gutiérrez, D.; Fernández, L.; Rodríguez, A. and García. (2019). Role of bacteriophages in the implementation of a sustainable dairy chain. Front Microbiol., 10: 1-14.

Hanlon, G.W. (2007). Bacteriophages: an appraisal of their role in the treatment of bacterial infections. Int. J. Antimicrob. Agents, 30(2): 118-128.

Harvell, C.D.; Mitchell, C.E.; Ward, J.R.; Altizer, S.; Dobson, A.P.; Ostfeld, R.S. and Samuel, M.D. (2002). Climate warming and disease risks for terrestrial and marine biota. Science, 296: 2158-2162. 
Hassan, S.W. (2017). Phenotypic characterization of Vibrio species: Application of indigenous phages for biological control of Vibrio in Aquaculture live feeds. Int. J. Curr. Microbiol. App. Sci., 6(6): 2760-2778.

Hassan, S.W.; Ali, S.M. and AlMisherfi, M.M. (2018). Isolation and molecular characterization of some marine Aeromonas phages: Protective effects for Nile tilapia infected with Aeromonas hydrophila. J. Pure. Appl. Microbiol., 12(3): 1175-1185.

Hofer, B.; Ruge, M. and Dreiseikelmann, B. (1995). The superinfection exclusion gene (sieA) of bacteriophage P22: identification and overexpression of the gene and localization of the gene product. J. Bacteriol., 177: 3080-3086.

Hsu, C.H.; Lo, C.Y.; Liu, J.K. and Lin, C.S. (2000). Control of the eel (Anguilla japonica) pathogens, Aeromonas hydrophila and Edwardsiella tarda by bacteriophages. J. Fish. Soc Taiwan., 27: 21-31.

Hutkins, R.W. (2008). Microbiology and Technology of Fermented Foods. Blackwell Publishing, Chicago.

Jofre, J.; Lucena, F.; Blanch, A.R. and Muniesa, M. (2016). Coliphages as model organisms in the characterization and management of water resources. Water, 8: $1-21$.

Johnson, M.L.; Wan, J.; Huang, S.; Cheng, Z.; Petrenko, V.A.; Kim, D-J.; Chen, IH.; Barbaree, J.M.; Hong, J.W. and Chin, B.A. (2008). A wireless biosensor using microfabricated phage-interfaced magnetoelastic particles. Sens Actuat A., 144: $38-47$.

Jover, L.F.; Chad Effler, T.; Buchan, A.; Steven W.; Wilhelm, S.W. and. Weitz, J.S. (2014). The elemental composition of virus articles: implications for marine biogeochemical cycles. Microbiol., 12: 519-528.

Kalatzis, P.; Castillo, D.; Katharios, P. and Middelboe, M. (2018). Bacteriophage interactions with marine pathogenic vibrios: implications for phage therapy. Antibiotics, 7: 1-23.

Katsamba, P. and Lauga, E. (2019). Hydrodynamics of bacteriophage migration along bacterial flagella. Phys. Rev. Fluids., 4: 013 101-1-013101-20.

Kazimierczak, J.; Wójcik1, E.; Witaszewska, J.; Guziński, A. E. and Dastych, J. (2019). Complete genome sequences of Aeromonas and Pseudomonas phages as a supportive tool for development of antibacterial treatment in aquaculture.

Virol. J., 16: 1-12. 
Keary, R.; McAuliffe, O.; Ross, R.P.; Hill, C.; O’Mahony, J. and Coffey, A. (2013). Bacteriophages and their endolysins for control of pathogenic bacteria. In: Mendez-Vilas, A. (Ed.), Microbial Pathogens and Strategies for Combatting Them: Science, Technology and Education. Formatex Research Center, Badajoz, Spain, 1028-1040 pp.

King, G. and Murray, N.E. (1995). Restriction alleviation and modification enhancement by the Rac prophage of Escherichia coli K-12. Mol. Microbiol., 16: 769-777.

Kirby, A.E. (2012). Synergistic action of gentamicin and bacteriophage in a continuous culture population of Staphylococcus aureus. PLOS One, 7(11): 1-9.

Kriss, A.E. and Rukina, E.A. (1947). Bacteriophages in the Sea. Rept U S S R Acad. Sci., 57: 833-836.

Kruger, D.H.; Barcak, G.J. and Smith, H.O. (1988). Abolition of DNA recognition site resistance to the restriction endonuclease EcoRII. Biomed. Biochim. Acta., 47: K1-K5.

Kumar., V.; Shivu, M.; Umesha, K. and Rajeeva, P. (2006). Isolation of Vibrio harveyi bacteriophages with a potential for biocontrol of this pathogen in hatchery environments. Aquaculture, 255 (1-4): 117-124.

Kutter, E. and Sulakvelidze, A. (2005). Bacteriophages: Biology and applications. CRC Press, Boca Raton.

Lakshmanan, R.S.; Guntupalli, R.; Hu, J.; Kim, D.J.; Petrenko, V.A.; Barbaree, J.M and Chin, B.A. (2007a). Phage immobilized magnetoelastic sensor for the detection of Salmonella typhimurium. J. Microbiol. Meth., 71: 55-60.

Lakshmanan, R.S.; Guntupalli, R.; Hu, J.; Petrenko, V.A.; Barbaree, J.M. and Chin. B.A. (2007b). Detection of Salmonella typhimuriumin fat free milk using a phage immobilized magnetoelastic sensor. Sens Actuat B., 126: 544-550.

Le, T.S.; Southgate, P.C.; O’Connor, W.; Poole, S. and Kurtböke, D. (2018b). Bacteriophages as biological control agents of enteric bacteria contaminating edible Oysters. Current. Microbiol., 27(5): 611-619.

Letchumanan, V.; Pusparajah, P.; Tan, L.T.H.; Yin, W.F.; Lee, L.H. and Chan, K.G. (2015). Occurrence and antibiotic resistance of Vibrio parahaemolyticus from shellfish in Selangor, Malaysia. Front Microbiol., 6: 1-1. 
Lindell, D.; Jaffe, J.D.; Johnson, Z.I.; Church, G.M. and Chisholm, S.W. (2005). Photosynthetic genes in marine viruses yield proteins during host infection. Nature, 438: 86-89.

Lopes, A.; Tavares, P.; Petit, M.A.; Guérois, R. and Zinn -Justin, S. (2014). Automated classification of tailed bacteriophages according to their neck organization. BMC Genomics, 15: 1-17.

Ly-Chatain. (2014). The factors affecting effectiveness of treatment in phages therapy. Front. Microbiol., 5: 1-7.

Maillou, J. and Dreiseikelmann, B. (1990). The sim gene of Escherichia coliphage P1: nucleotide sequence and purification of the processed protein. Virology, 175: $500-507$.

Mansour, N.M. (2018). Bacteriophages are natural gift, could we pay further attention!. J Food Microbiol., 2(1): 1-3.

Marza, J.A.; Soothill, J.S.; Boydell, P. and Collyns, T.A. (2006). Multiplication of therapeutically administered bacteriophages in Pseudomonas aeruginosa infected patients. Burns., 32: 644-646.

Matsuoka, S.; Hashizume, T.; Kanzaki, H.; Iwamoto, E.; Park, S.C.; Yoshida, T. and Nakai, T. (2007). Phage therapy against $\beta$-hemolytic streptococcicosis of Japanese flounder Paralichthys olivaceus. Fish Pathol., 42: 181-189.

McGrath, S.; Seegers, J.F.M.; Fitzgerald, G.F. and van Sinderen, D. (1999). Molecular characterization of a phage encoded resistance system in Lactococcus lactis. Appl. Environ. Microbiol., 65: 1891-1899.

Middelboe, M. and Brussaard, C.P. (2017). Marine viruses: Key players in marine ecosystems. Viruses, 9: 1-6.

Moak, M. and Molineux, I. J. (2000). Role of the Gp16 lytic transglycosylase motif in bacteriophage T7 virions at the initiation of infection. Mol. Microbiol., 37: 345355.

Nanduri, V.; Balasubramanian, S.; Sista, S.; Vodyanoy, V.J. and Simonian, A.L. (2007). Highly sensitive phage-based biosensor for the detection of betagalactosidase. Anal. Chim. Acta., 589: 166-172.

Ninawe, A. S.; Sivasankari, S.; Ramasamy, R. G.; Seghal Kiran, G. and Selvin, J. (2020). Bacteriophages for aquaculture disease control. Aquacult. Int.. https://doi.org/10.1007/s10499-020-00567-4. 
Oechslin, F. (2018). Resistance development to bacteriophages occurring during bacteriophage therapy. Viruses, 10: 1-23.

Olsen, E.V.; Sorokulova, I.B.; Petrenko, V.A.; Chen, I.H.; Barbaree, J.M. and Vodyanoy, V.J. (2006). Affinity selected filamentous bacteriophage as a probe for acoustic wave biodetectors of Salmonella typhimurium. Biosens. Bioelectron.., 21: 1434-1442.

Pal, S. (2015). Phage therapy an alternate disease control in Aquaculture: A review on recent advancements. IOSR J. Agricult. Veter. Sci., 8(9): 68-81.

Park, S.P.; Aoki, T. and Jung, T.S. (2012). Pathogenesis of and strategies for preventing Edwardsiella tarda infection in fish. Vet. Res., 43: 1-11.

Park, S.C.; Shimamura, I.; Fukunaga, M.; Mori, K.I. and Nakai, T. (2000). Isolation of bacteriophages specific to a fish pathogen, Pseudomonas plecoglossicida, as a candidate for disease control. Appl. Environ Microbiol., 66: 1416-1422.

Payne, R.J. and Jansen, V.A. (2001). Understanding bacteriophage therapy as a densitydependent kinetic process. J. Theor Biol., 208: 37-48.

Petrenko, V.A. (2008). Landscape phage as a molecular recognition interface for detection devices. Microelectronics J., 39: 202-207.

Pingoud, A.; Fuxreiter, M.; Pingoud, V. and Wende, W. (2005). Type II restriction endonucleases: structure and mechanism. Cell .Mol. Life. Sci., 62: 685-707.

Pradeep Ram, A. S.; Arnous, B.; Danger, M.; Carrias, J.F.; Lacroix, G. and SimeNgando, T. (2010). High and differential viral infection rates within bacterial 'morphopopulations' in a shallow sand pit lake (Lac de Créteil, France). FEMS Microb. Ecol., 74: 83-92.

Putra, R.D. and Lyrawati, D. (2020). Interactions between bacteriophages and eukaryotic cells. Scientifica, 2020, 1-8 https://doi.org/10.1155/2020/3589316.

Rifat, D.; Wright, N.T.; Varney, K.M.; Weber, D.J. and Black, L.W. (2008). Restriction endonuclease inhibitor IPI of bacteriophage T4: a novel structure for a dedicated target. J. Mol. Biol., 375: 720-734.

Rohwer, F. and Edwards, R. (2002). The phage proteomic tree: a genome based taxonomy for phage. J. Bacteriol., 184: 4529-4535.

Rohwer, F. and Thurber, R. V. (2009). Viruses manipulate the marine environment. Nature, 459: 207-212. 
Rosenberg, E. and Ben-Haim, Y. (2002). Microbial diseases of corals and global warming. Environ. Microbiol. 4: 318-326.

Roux, S.; Enault, F.; Robin, A.; Ravet, A.; Personnic, S. and Theil, S. (2012). Assessing the diversity and specificity of two freshwater viral communities through metagenomics. PLOS ONE, 7: 1-12.

Sekar, A. and Kandasamy, K. (2013). Bacterial viruses in marine environment and their ecological role and bioprospecting potential: a review. Int. J. Curr. Microbiol. App. Sci., 2: 151-163.

Silva, Y.J.; Moreirinha, C.; Pereira, C.; Costa, L.; Rocha, R.J., Cunha, A., Gomes, N.C., Calado. R., J.M. and Almeida, C. (2016). Biological control of Aeromonas salmonicida infection in juvenile Senegalese sole (Solea senegalensis) with Phage AS-A. Aquaculture, 450(1): 225-233.

Sime-Ngando, T. (2014). Environmental bacteriophages: viruses of microbes in aquatic ecosystems. Front Microbiol., 5: 1-14.

Sturino, J.M. and Klaenhammer, T.R. (2006). Engineered bacteriophage-defence systems in bioprocessing. Nature. Rev. Microbiol., 4: 395-404.

Sugden, R.; Kelly, R. and Davies, S. (2016). Combatting antimicrobial resistance globally. Nat. Microbiol., 1: 1-2.

Suttle, C.A. (2005). Viruses in the sea. Nature, 437: 356-361.

Suttle, C.A. (2007). Marine viruses: major players in the global ecosystem. Nat. Rev. Microbiol., 5: 801-812.

Thung, T.Y.; Lee, E.; Premarathne, J.M.; Nurzafirah, M.; Kuan, C.H.; Elexson, N.; Tan, C.W.; Malcolm, T.T.H.; New, C.Y.; Ramzi, O.S.B.; Nuzul, N.J.; Azira, N.A.M.; Ungku Fatimah, U.Z.A. and Son, Rn. (2018). Bacteriophages and their applications. Food Res., 2(5): 404-414.

Tukmechi, R.; Hobbenaghi, H.; Holasoo, R. and Morvaridi, A. (2009). Streptococcosis in a pet fish, Astronotus Ocellatus: A case study A. World. Sci. Eng. Tech., 49: 14-15.

Van Belleghem, J.; Krystyna, Dabrowska, K.; Vaneechoutte, M.; Barr, J. and Bollyky, P. (2019). Interactions between bacteriophage, bacteria and the mammalian system.Viruses, 11: 1-22. 
Walkinshaw, M.D.; Taylor, P.; Sturrock, S.S.; Atanasiu, C.; Berge, T.; Henderson, R.M.; Edwardson, J.M. and Dryden, D.T. (2002). Structure of Ocr from bacteriophage T7, a protein that mimics B-form DNA. Mol. Cell., 9: 187-194.

Weinbauer, M.G. (2004). Ecology of prokaryotic viruses. FEMS Microbiol. Rev., 28(2): $127-181$.

Wigington, C.H.; Sonderegger, D.L.; Brussaard, C.P.D.; Buchan, A.; Finke, J.F.; Fuhrman, J.; Lennon, J.T.; Middelboe, M.; Suttle, C.A.; Stock, C.; Wilson WH.; Wommack, K.E.; Wilhelm, S.W. and Weitz, J.S. (2016). Reexamining the relationship between virus and microbial cell abundances in the global oceans. Nat. Microbiol., 1: 1-9.

Wilson, G.G. and Murray, N.E. (1991). Restriction and modification systems. Annu. Rev. Genet., 25: 585-627.

Woese, C.R.; Kandler, O. and Wheelis, M.L. (1990). Towards a natural system of organisms: proposal for the domains Archaea, Bacteria, and Eucarya. Proc. Natl .Acad. Sci U. S .A., 87: 4576-4579.

Zhang, H.; Xu, Y.; Huang, Q.; Yi, C.; Xiao, T. and Li, Q. (2013). Natural phage nanoparticle-mediated real-time immuno-PCR for ultrasensitive detection of proteinmarker. Chem Commun., 49: 3778-3780.

Web sites

https://vignette.wikia.nocookie.net 